\title{
REVIEW
}

\section{Crucial role of renin-angiotensin system in the patho- genesis of atherosclerosis}

\author{
Masataka Sata 1 and Daiju Fukuda ${ }^{2}$ \\ ${ }^{1}$ Department of Cardiovascular Medicine, Institute of Health Bioscience, the University of Tokushima \\ Graduate School, Tokushima, Japan ; and 2.Cardiovascular Division, Department of Medicine, Brigham \\ and Women's Hospital, Harvard Medical School, Boston, U.S.A.
}

\begin{abstract}
The renin-angiotensin system (RAS) has been demonstrated to play a critical role in the initiation and progression of atherosclerosis, thereby contributing to development of cardiovascular diseases. Angiotensin II (Ang II), a major substrate in RAS, stimulates atherosclerosis through various deleterious effects such as endothelial dysfunction, cellular proliferation and inflammation. Recently, local RAS in vasculature is reported to play an important role. Many of these atherogenic actions of Ang II are mediated by reactive oxygen species (ROS). Investigation of the role of ROS and inflammation induced by RAS may provide a clue to understanding the pathophysiology of atherosclerotic diseases, and may lead to a new therapeutic strategy. J. Med. Invest. 57 : 12 25, February, 2010
\end{abstract}

Keywords : atherosclerosis, renin-angiotensin system, reactive oxygen species, inflammation

\section{INTRODUCTION}

The renin-angiotensin system (RAS) has been considered as a circulating hormonal system that regulates blood pressure, blood flow, fluid volume and electrolyte balance $(1,2)$. Angiotensinogen produced in the liver is cleaved to angiotensin (Ang) I in circulation by renin that is secreted from the kidney. Ang I is cleaved to Ang II by angiotensin converting enzyme (ACE) that is mainly distributed in pulmonary circulation. Ang II plays a main role in the RAS by interacting with its specific receptor, Ang II type 1 receptor (AT1R). Ang II-AT1R interaction causes vasoconstriction and aldosterone release from the adrenal gland. This classical view of the RAS has been expanded by recent findings that RAS

Received for publication December 25, 2009 ; accepted January $8,2010$.

Address correspondence and reprint requests to Masataka Sata, $\mathrm{MD}, \mathrm{PhD}$, Department of Cardiovascular Medicine, Institute of Health Biosciences, the University of Tokushima Graduate School, 3-18-15 Kuramoto-cho, Tokushima 770-8503, Japan and Fax : +81-88-633-7894. is activated locally, particularly in the heart $(3,4)$, the vessel wall $(5-7)$, the kidney $(8,9)$ and the brain (10-12). There are RAS components in these tissues, allowing local synthesis of Ang peptides. Recent reports also identified other receptors (13-15) and angiotensin-related peptides such as Ang (1-7) (16). Ang II was also reported to be generated by other enzymes such as chymase (17). These findings indicate that RAS could be activated locally and regulated by the complicated crosstalk of the RAS components in each organ.

AT1R blockers (ARBs) specifically block Ang II binding to AT1R. Eventually, Ang II is directed to stimulate AT2R. On the other hand, ACE inhibitors (ACEIs) suppress angiotensin II production. ACEIs also inhibit break down of bradykinin, leading to increase in nitric oxide production. It has been reported that ARBs or ACEIs exert various favorable effects on endothelial function $(18,19)$, cardiac function $(20,21)$, cerebral vascular function $(22,23)$ and renal function $(24,25)$ other than blood pressure lowering. These findings suggest that blockade of 
RAS is an effective strategy for organ protection. In fact, many clinical studies demonstrated that AT1R blockers (ARBs) or ACE inhibitors are effective for patients with cardiovascular, cerebrovascular and renal diseases $(20,24,26,27)$.

Atherosclerosis occurs in whole arteries and results in various organ damages, including myocardial infarction, cerebral infarction, and peripheral arterial diseases, the main cause of death in Western countries (28). Atherosclerosis is considered to be one of the chronic inflammatory diseases $(29,30)$. Ang II has significant pro-inflammatory actions on the vessel wall, leading to progression and destabilization of atherosclerotic lesions (29, 31). Although multifactorial in etiology, continuous recruitment of circulating leukocytes into the vessel wall plays crucial roles in the pathogenesis of atherosclerosis. Inflammatory cells detected in atherosclerotic lesions are derived from bone marrow. A locally activated RAS has been suggested to contribute to differentiation and proliferation of bone marrow-derived cells (32-34). Recently, we proposed a hypothesis that the local RAS in bone marrow plays crucial roles in atherosclerosis $(35,36)$. We demonstrated that Ang II-AT1R pathway in bone marrow contributes to atherosclerotic development in the hypercholesterolemic mice. In this review, we briefly summarize recent evidence on the roles of RAS in the pathogenesis of atherosclerosis and in the differentiation of bone marrow cells. We describe our findings on potential participation of bone marrow RAS in progression and destabilization of atherosclerotic plaques.

\section{LOCAL EFFECTS OF AN ACTIVATED RAS IN VASCULATURE}

A growing body of evidence suggests that atherosclerosis is a chronic inflammatory disease (29, $30)$. Recent advances in immunology have dissected several molecular pathways that induce and promote inflammatory responses in atherosclerotic lesions. The RAS serves as a key player in the pathogenesis of atherosclerosis by stimulating a series of coordinated cellular and molecular events observed in the lesions (37-41). It is now well established that Ang II has significant pro-inflammatory actions on the vessel wall, leading to progression of atherosclerosis (29). There are two different types of Ang II receptors, AT1R and AT2R, in mammals (13). Both AT1R and AT2R have been identified in the vessel wall, although AT1R is believed to mediate most of the atherogenic actions of Ang II $(42,43)$. The greatest AT1R density has been found on vascular smooth muscle cells and endothelial cells. In the vascular wall, ACE is readily detectable on endothelial cells and smooth muscle cells (44-46). Thus, most of the components of RAS could be detected in vasculature $(47,48)$. RAS is activated locally in the atherosclerotic lesions (49) and in the damaged vessels (50). Thus, these results suggest that not only systemic but also local Ang II-AT1R pathway could contribute to initiation and progression of atherosclerosis.

\section{EFFECTS OF RAS ON VASCULAR CELLS}

Ang II up-regulates expression of adhesion molecules $(37,51)$, chemokines $(39,52)$ and cytokines $(53,54)$. These molecules induce endothelial cell dysfunction (55), oxidation and uptake of LDL (56, 57), and proliferation of smooth muscle cells (58). In advanced atherosclerotic lesions, Ang II stimulates expression of matrix metalloproteinases (MMPs) (59-61) and plasminogen activator inhibitor-1 (62), leading to destabilization of atherosclerotic plaque and alteration of fibrinolytic balance. Ang II also upregulates expression of VEGF that promotes adventitial angiogenesis (63-65) (Fig. 1).

Conversely, previous reports demonstrated that

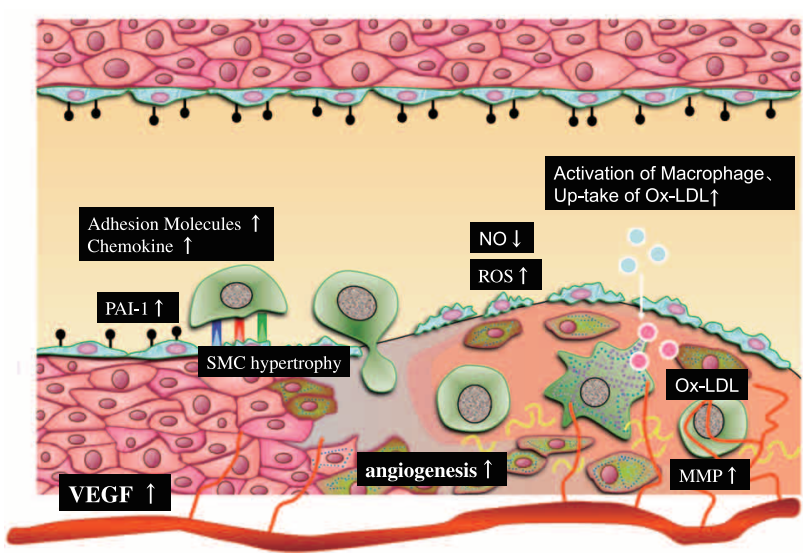

Fig. 1 Atheropromoting effects of angiotensin II Angiotensin II (Ang II) impairs NO synthesis and promotes reactive oxygen species production by endothelial cells, causing endothelial dysfunction. Ang II also promotes adhesion and infiltration of monocytes/macrophages by up-regulating adhesion molecules and chemokines such as MCP-1. Ang II promotes oxidation of LDL and foam cell formation of macrophages. Ang II functions to destabilize atherosclerotic plaques by activating macrophages, which induce apoptosis of smooth muscle cells and proteolysis of collagen by MMPs. Ang II promotes periadventitial angiogenesis by up-regulating VEGF expression. 
inhibition of the Ang II-AT1R pathway reduces atherosclerosis $(36,66-68)$. It is generally assumed that the beneficial effects obtained by Ang II-AT1R blocking are mediated by reduction of oxidative stress, inhibition of inflammation and improvement of endothelial cell function $(66,67,69,70)$. We generated ApoE-/-AT1aR-/- double knockout mice by crossbreeding ApoE-/-AT1aR+/+ mice and ApoE+/+ AT1aR-/- mice (35). We also administered ARB, olmesartan, into ApoE-/- AT1aR+/+ mice. Both genetic ablation and pharmacological blockade of AT1R effectively suppressed atherosclerotic lesion formation in ApoE deficient mice. Moreover, genetic disruption or pharmacological blockade of AT1R resulted in reduced lipid deposition and increased collagen contents in the atheroma. These results demonstrated that blockade of Ang II-AT1R pathway not only reduces atherosclerotic lesions but also stabilizes the plaque (35).

It should be noted that the production of Ang II could be increased and may act on the AT2R, when AT1R is genetically disrupted or pharmacologically blocked (71). Previous reports suggested an antiatherogenic effect of AT2R, although its function and distribution are still under debate (72-74). Wu et al. demonstrated that organ-protective actions of valsartan, an ARB, were attenuated in AT2R-deficient mice, suggesting that beneficial effects of AT1R blockers are at least partly due to AT2R receptor stimulation $(75,76)$. AT2R stimulation interacts with AT1R stimulation at intracellular signaling molecules, such as through activation of phosphatase (77). In fact, Iwai et al. demonstrated that AT2R stimulation attenuates atherosclerosis through inhibition of oxidative stress and that the anti-atherosclerotic effect of an ARB could be at least partly due to AT2R stimulation by analyzing AT2R/ApoE-doubleknockout mice (73).

\section{ROLES OF REACTIVE OXYGEN SPECIES IN ATHEROGENESIS}

Accumulating evidence indicates that vascular reactive oxygen species (ROS) play a crucial role in atherogenesis. Among many ROS generator, nicotinamide dinucleotide phosphate (NAD $(\mathrm{P}) \mathrm{H})$ oxidase-dependent pathway is important in vascular system (78). Barry-Lane et al. demonstrated that $\mathrm{NAD}(\mathrm{P}) \mathrm{H}$ oxidase is important in the pathogenesis of atherosclerosis by analyzing the genetically modified mice that are deficient for both apolipoprotein
E (ApoE) and p47phox, one subunits of $\mathrm{NAD}(\mathrm{P}) \mathrm{H}$ oxidase (79). In this study, the double knockout mice showed significant reduction in atherosclerotic lesion compared with that of ApoE-deficient mice. ROS acts not only as a modulator of vascular tonus but also as a second messenger to alter the vascular cell phenotypes. ROS activates mitogen-activated protein kinase (80), Akt (81), and JAK (janus kinase)/STAT (signal transducers and activators of transcription) (82) pathways. These signals play a crucial role in cell proliferation, apoptosis and phenotypic modification that are observed in atherosclerotic lesions.

Association between RAS and ROS has been investigated extensively (5). Ang II induces production of ROS, one of the most important mediators of the atherogenic actions of RAS (70). Although Ang II up-regulates expression of cytokines such as interleukin- 6 and tumor necrosis factor- $\alpha$, pharmacological blockade of AT1R with ARBs would not be so effective to inhibit cytokine production completely. It was demonstrated that cytokines such as TNF- $\alpha$, IL- $1 \beta$ and IFN- $\gamma$ increase mitochondrialand NADPH oxidase-generated ROS (83). Thus, the in vivo inhibition of intracellular ROS production by blocking vascular AT1R may play an adjunct rather than a major role to prevent or reduce atherogenesis. The above suggestion could be also compatible with the accumulating findings that AT1R blocker could only have a modest effect on atherosclerosis diseases in patients (84).

\section{ROLES OF INFLAMMATORY CELLS IN ATHEROGENESIS}

In initiation and progression of atherosclerotic lesions, RAS is activated locally and stimulates expression of vascular cellular adhesion molecule-1, intracellular adhesion molecule- 1 and monocyte chemotactic protein-1 (MCP-1) (37, 39, 51, 52). These molecules accelerate recruitment of inflammatory cells into the vessel walls. It is generally believed that the vascular endothelium serves as an inflammatory barrier by providing a nonadherent surface to leukocytes. However, upon Ang II stimulation, endothelium turns to promote infiltration of inflammatory cells by expressing adhesion molecules and chemokines. After migrating into the vessel wall, monocytes transform into macrophages and contribute to lipid deposition in the plaque $(57,85)$. Monocytes/macrophages secret chemokines (86) and 
MMPs (60), leading to acceleration of atherosclerotic lesion development. Moreover, recruited leukocytes themselves have $\mathrm{NAD}(\mathrm{P}) \mathrm{H}$ oxidase subunits and serve as a source of ROS $(87,88)$. Thus, activated RAS promotes interaction between circulating leukocytes and vascular cells, an important step in the pathogenesis of atherosclerosis $(40,41)$. High levels of ACE expression and Ang II have been shown in experimental and human atherosclerotic lesions (89-91). In human atherosclerotic lesions, ACE, Ang II, and its receptor are co-localized at the areas of inflammation (5). Taken together, these results suggest that local effects of an activated RAS in vessel walls promote infiltration of inflammatory cells into the vessel walls, a key feature of atherosclerosis.

\section{LOCAL EFFECTS OF AN ACTIVATED RAS IN BONE MARROW}

Bone marrow is a highly organized organ. All blood cells derive from hematopoietic stem cells through complex steps of division and maturation. Previous reports elucidated the surface receptors, cytokines, and growth factors that potentially regulate hematopoiesis (92-94). However, the precise mechanism by which the proliferation and differentiation of hematopoietic stem cells are regulated is not fully understood.

Randomized clinical trials have proved beneficial effects of ACE inhibitors or ARBs in the treatment of cardiovascular diseases $(21,23)$. However, it was reported that ACE inhibitors or ARBs may have suppressive effects on hematological processes. It is reported that ACE inhibitors induced anemia and leukocytopenia (95-97). ACE inhibitors and ARBs have been shown to effectively reduce hematocrit values in patient with renal transplantation $(98,99)$. Haznedaroglu et al. proposed the existence of a locally activated RAS in bone marrow that contributes to hematological processes (100). Others also demonstrated the presence of RAS components in bone marrow and circulating blood cells. Rodgers et al. showed the presence of AT1R in CD $34^{+} \mathrm{CD} 38^{+}$ cells, CD34 ${ }^{+} \mathrm{CD} 38$ cells and lymphocytes (101). The authors demonstrated that Ang II accelerated colony formation of hematopoietic progenitor cells from murine lineage negative bone marrow cells in a dose dependent manner. Ang II also stimulated differentiation of human CD34+ hematopoietic progenitors from cord blood. The effects of Ang II on hematopoietic progenitors were clearly inhibited by an ARB, losartan. It was also reported that Ang II and Ang (1-7) accelerated recovery of circulating leukocytes and the myeloid lineage cells in bone marrow after chemotherapy and irradiation (102, 103). Similarly, other reports demonstrated that RAS components in bone marrow contribute to hematopoiesis (104-106). On the other hand, several papers reported that a local RAS in bone marrow plays a role in the pathological hematopoiesis (107, 108). bone marrow stromal cells also express AT1R, whose activation possibly causes secretion of growth factors or cytokines that increase hematopoietic progenitor cells (109). Thus, it is likely that angiotensin peptides are potential stimulators of proliferation and differentiation of multiple hematopoietic lineages under physiological and pathological conditions.

\section{ANG II STIMULATES CONTRIBUTION OF BONE MARROW-DERIVED CELLS TO THE PATHOGENESIS OF ATHEROSCLEROSIS}

Recently, we proposed that bone marrow-derived cells significantly contribute to pathogenesis of atherosclerosis $(35,36,110-117)$. This phenomenon was confirmed not only in various animal models of vascular diseases, but also in human samples (118, 119). Ang II is supposed to promote contribution of bone marrow-derived cells to atherosclerosis by enhancing their mobilization, recruitment, differentiation, and proliferation $(35,36)$. To confirm this notion, we performed bone marrow transplantation from GFP (Green Fluorescent Proteins) +/+ApoE-/mice to GFP-/-ApoE-/- mice. Administration of Ang II to these bone marrow chimeric mice promoted atherosclerosis lesion formation, which was associated with increased infiltration of bone marrowderived GFP-positive cells to the lesion $(35,36)$ (Fig. 2A). We also observed that Ang II infusion increased the number of smooth muscle progenitor cells, which are peripheral blood cells that turn to $\alpha$-smooth muscle actin-positive cells after culture in the presence of PDGF-BB (116) (Fig. 2B). These smooth muscle-like cells expressed abundant matrix metalloproteinase-9 (MMP-9), which substantially contribute to destabilization of atherosclerotic plaques. 
A

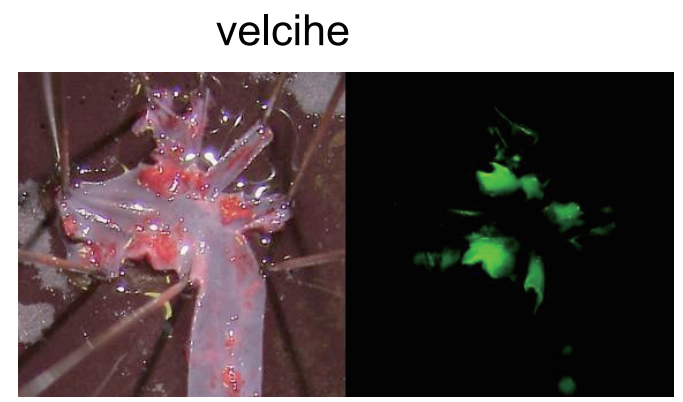

B

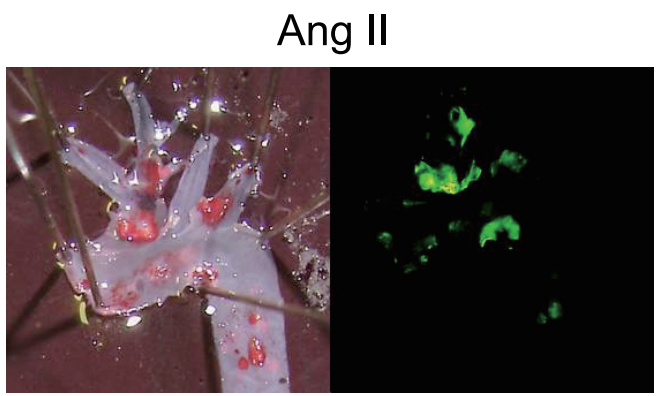

Human peripheral blood-derived
smooth muscle-like cells

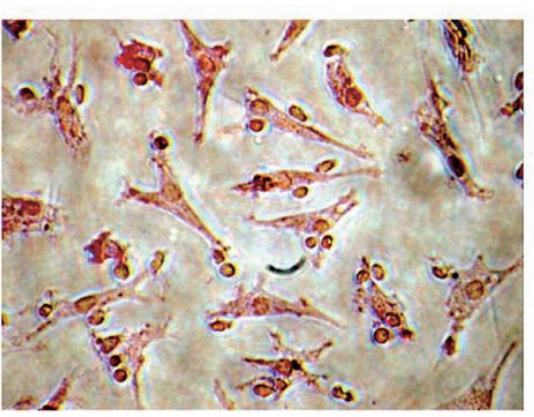

$\alpha-S M A$
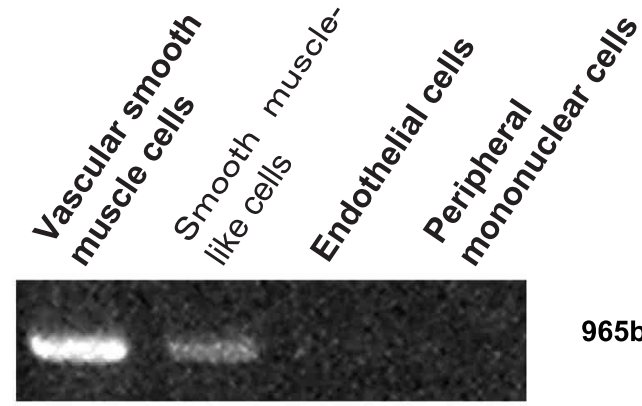

965bp

GAPDH

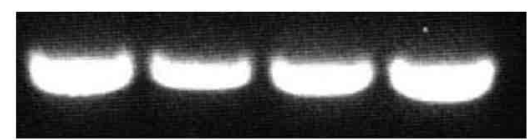

452bp

MMP-9

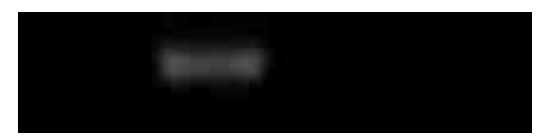

$70 \mathrm{bp}$

Fig. 2 Ang II promotes accumulation of macrophages in atherosclerotic plaque

A. Ang II infusion into the bone marrow-chimeric mice promoted atherosclerotic lesion formation as determined by en face Sudan IV staining. Bone marrow-derived GFP-positive cells accumulated at the sites of atherosclerosis.

B. $\alpha$-smooth muscle actin-positive cells could be obtained from the culture of human peripheral mononuclear cells. Those smooth muscle-like cells expressed MMP-9.

\section{ROLE OF BONE MARROW RAS IN THE PATHOGENESIS OF ATHEROSCLEROSIS}

Although interaction between leukocytes and vascular cells plays a crucial role in the pathogenesis of atherosclerosis, it remained to be elucidated whether a local RAS, especially the Ang II-AT1R pathway, in bone marrow contributes to vascular diseases. To evaluate the potential participation of AT1aR in bone marrow in the pathogenesis of atherosclerosis, we generated several combinations of bone marrow chimeric mice in a murine model of hyperlipidemia and atherosclerosis (120). In rodents, two AT1R subtypes, AT1aR and AT1bR, have been identified. In the vasculature, ATlaR is predominant and mediates most of the physiological and pathophysiological responses to Ang II in mice $(121,122)$. We also revealed that AT1aR was abundantly expressed in bone marrow, whereas other receptors were hardly detected in bone marrow cells by RT-PCR.

At first, we performed bone marrow transplantation (BMT) from the ApoE-/-AT1aR-/- mice to the ApoE-/-AT1aR-/- mice (BMT ApoE-/AT1aR-/-.. ApoE-/-ATlaR- mice). These bone marrow chimeric mice had no ATlaR in their body. We also performed BMT from the ApoE-/-AT1aR+/+ mice to the ApoE-/-AT1aR-/mice (BMT ${ }^{\text {ApoE- }- \text { ATlaR }+/+\cdots>\text { ApoE- } / \text { ATlaR } /-}$ mice). These bone marrow chimeric mice had AT1aR in bone marrow, but not in their innate vascular cells. We infused Ang II $(5 \mathrm{mg} / \mathrm{kg} /$ day $)$ into these bone marrow chimeric mice for 8 weeks using an osmotic mini-pump. There was no significant difference in systolic blood pressure or plasma cholesterol level between these BMT mice. After 8 weeks of infusion, en face Sudan IV staining of the aortic arch revealed that atherosclerotic lesions in the $\mathrm{BMT}^{\mathrm{ApoE}-/ \text {-ATlaR+/+-.> ApoE-/ATlaR-/ }}$ mice were significantly

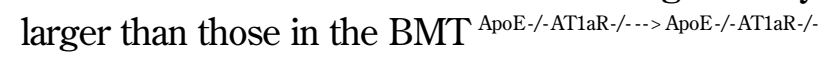
mice. Histological analysis of atherosclerotic lesions 
in the aortic root revealed that lipid deposition detected by oil red $\mathrm{O}$ staining was significantly accelerated in the BMT ${ }^{\mathrm{ApoE}-/-\mathrm{AT} \text { TaR }+/+\cdots>\mathrm{ApoE}-/ \text { ATlaR-/ }}$ mice com-

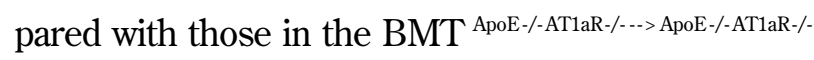
mice. Collagen content was significantly decreased

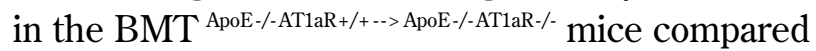
with that in the BMT ApoE- - ATlaR- $/ \cdots>$ ApoE- $/$ ATlaR- $/$ mice as determined by Sirius red staining. Taken together, these results suggest that bone marrow transplantation from the ApoE-/-AT1aR+/+ animals to the ApoE-/-AT1aR-/- mice could restore Ang II-induced acceleration of atherosclerosis and plaque destabilization, even when the recipient vascular cells did not express AT1aR (35).

Next, to investigate the role of bone marrow AT1aR and to keep track of bone marrow-derived cells in the process of atherosclerotic lesion progression, we replaced the bone marrow of the ApoE-/-ATlaR+/+ mice with that of the ApoE-/ATlaR-/-GFP+/+ mice (BMT ApoE- - -ATlaR $-\cdots \rightarrow$ ApoE $-/$ ATlaR $+/+$ mice) or the ApoE-/-AT1aR+/+GFP+/+ mice (BMT ${ }^{\mathrm{ApoE}-/-\mathrm{ATIaR}+/++\rightarrow \mathrm{ApoE}-/-\mathrm{ATlaR}+/+}$ mice). The former bone marrow chimeric mice lacked AT1aR only in bone marrow, and the latter chimeric mice had AT1aR in both bone marrow and vasculature. In these bone marrow chimeric mice, we compared the effects of continuous Ang II infusion on atherosclerotic lesion formation. Ang II ( $5 \mathrm{mg} / \mathrm{kg} /$ day) was infused after BMT for 8 weeks. Atherosclerotic lesion formation was significantly attenuated in the BMT ${ }^{\text {ApoE- }- \text { ATlaR }-\cdots>\text { ApoE }-/ \text { AT1aR+/+ }}$ compared with that in the BMT ${ }^{\mathrm{ApDE}-/-\mathrm{AT} \text { TaR }+/+\cdots>\mathrm{ApDE}-/-\mathrm{ATlaR}+/+}$ mice as determined by en face Sudan IV staining of the aortic arch. In these two types of bone marrow chimeric mice, there was no significant difference in blood pressure or total cholesterol level. In atherosclerotic plaques in the aortic root, the BMT ${ }^{\text {ApoE- }- \text { ATIaR- } / \ldots>\text { ApoE- }- \text { ATlaR }+/+}$ mice showed significantly reduced lipid deposition and increased collagen content compared with those in the BMT ${ }^{\mathrm{ApoE}-/-\mathrm{ATIaR}+/+->\mathrm{ApoE}-/ / \mathrm{ATIaR}+/+}$ mice. These results suggest that AT1aR in bone marrow-derived cells may play a role in the pathogenesis of accelerated atherosclerosis induced by Ang II. Infiltration of macrophage into the lesions was significantly

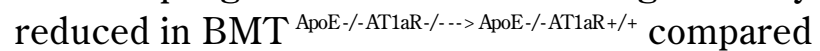
with that in BMT ${ }^{\mathrm{ApoE}-/ \mathrm{ATIaR}+/+->\mathrm{ApoE}-/ \mathrm{ATTaR}+/+}$ mice as determined by immunostaining against MOMA2. Lack of AT1aR in bone marrow cells decreased atherosclerotic lesion progression and stabilized plaques, despite the existence of AT1aR in vascular cells (35).

We examined gene expression in the plaques by means of a laser microdissection system and quantitative RT-PCR after 4 weeks infusion of Ang II. Expression of MMP-9 and MCP-1 in the BMT $^{\text {ApoE }-/ \text { ATlaR }-\cdots>\text { ApoE }-/ \text { AT1aR }+/+}$ mice was significantly suppressed compared with those in the BMT $^{\text {ApoE- }- \text {-ATlaR+/+- }>\text { ApoE- } / \text { ATlaR }+/+}$ mice. On the other hand, there was no significant difference in VCAM-1 expression between the two bone marrow transplantation mice. Immunohistochemical analysis revealed that accumulation of bone marrow-derived GFP-positive cells was significantly attenuated in the BMT $^{\text {ApoE}-/ \text { ATlaR } / / \ldots>\text { ApoE }-/ \text { ATlaR }+/+}$ mice compared with that in the BMT ${ }_{\text {ApoE- }-/ A T l a R+/+\cdots>A p o E-/-A T l a R+/+}$ mice. Most of the bone marrow-derived cells in the lesions were positive for macrophage marker. Furthermore, the percentage of bone marrow-derived GFP-positive cells among MMP-9-positive cells or MCP-1-positive cells was greater in the BMT ${ }^{\mathrm{ApoE}-/ \mathrm{ATlaR}+++\cdots>\mathrm{ApEE}-/ \mathrm{ATlaR}+/+}$ mice than in the BMT ApoE- $/$ ATlaR- $/ \ldots>$ ApoE- $/$ ATlaR $+/+$ mice, suggesting that AT1aR in bone marrow could influence the instability of the atherosclerotic lesions (35). Our findings indicate that AT1aR expressed not only on vascular cells but also on bone marrow cells plays a role in the pathogenesis of atherosclerosis, at least in part. Consistent with our results, contribution of AT1aR in bone marrow cells to the pathogenesis of atherosclerosis was demonstrated in LDL-receptor-deficient mice (123).

It is a generally accepted view that atherosclerotic lesions are initiated by endothelial cell damage, followed by monocyte/macrophage adhesion and invasion as well as smooth muscle cell migration and proliferation $(30,124)$. Although there are a number of cellular and molecular differences, restenosis after angioplasty shares an important pathophysiological process with atherosclerosis, where injuries to the endothelium are followed by impaired reendothelialization $(125,126)$. It has been believed that re-endothelialization is caused only by migration and proliferation of adjacent endothelial cells in the vessel wall (127). However, accumulating evidence indicates that bone marrow derived endothelial progenitor cells (EPCs) also participate in this process (128-131). EPC-dependent neovascularization has been implicated in collateral development in occlusive vascular diseases $(129,132-135)$. Bone marrow cells including stem cells express AT1R. Thus, it is possible that a local RAS in bone marrow has a role in EPC biology leading to neovascularization. Actually, it was demonstrated that activation of RAS stimulates EPC proliferation and neovascularization (136). These studies suggest that 
ROS may be involved in the balance between selfrenewal and differentiation of progenitors and that anti-oxidant may play a role in preservation of stemness of progenitors (137-139). Murohara and his colleagues showed that the Ang II-AT1R pathway plays an important role in ischemia-induced angiogenesis by supporting inflammatory cell infiltration and angiogenic cytokine expression (140). On the other hand, it was reported that blockade of RAS increase the number of EPC and neovascularization in animals models of metabolic diseases (141-143). These studies suggested that Ang II accelerates the onset of EPC senescence by a gp91phox-mediated increase of oxidative stress leading to impairment of EPC proliferation. Under pathological conditions, RAS may be over-activated and the excess production of Ang II might accelerate EPC senescence, resulting in the impairment of EPC function. Future study is required to confirm that RAS is essential for EPC proliferation and neovascularization but excessive activation of RAS may turn to enhance senescence and dysfunction of EPCs (117).

\section{CONCLUSIONS}

Our findings demonstrate that AT1aR expressed not only on vascular cells but also on bone marrowderived cells plays a role in the pathogenesis of atherosclerosis, at least in part, by accelerating infiltration of bone marrow-derived inflammatory cells in the vessel wall $(35,113,144)$. Therefore, blockade of AT1R not only in vascular cells but also in bone marrow could be an important strategy to prevent progression and destabilization of atherosclerotic plaques.

\section{ACKNOWLEDGEMENT}

This study was supported in part by the Program for Promotion of Basic and Applied Researches for Innovations in Bio-oriented Industry and by grants from the Ministry of Education, Culture, Sports, Science and Technology (Knowledge Cluster and New Research Area) and the Ministry of Health, Labor and Welfare of Japan.

\section{REFERENCES}

1. Oparil S, Haber $\mathrm{E}$ : The renin-angiotensin system (first of two parts). N Engl J Med 291 : 389-401, 1974

2. Oparil S, Haber E : The renin-angiotensin system (second of two parts). N Engl J Med 291 : 446-457, 1974

3. Cohn JN, Tognoni G : A randomized trial of the angiotensin-receptor blocker valsartan in chronic heart failure. N Engl J Med 345 : 16671675, 2001

4. Yamagishi H, Kim S, Nishikimi T, Takeuchi $\mathrm{K}$, Takeda $\mathrm{T}$ : Contribution of cardiac renin-angiotensin system to ventricular remodelling in myocardial-infarcted rats. J Mol Cell Cardiol $25: 1369-1380,1993$

5. Dzau VJ : Theodore Cooper Lecture : Tissue angiotensin and pathobiology of vascular disease : a unifying hypothesis. Hypertension 37 : 1047-1052, 2001

6. Dzau VJ, Re R: Tissue angiotensin system in cardiovascular medicine. A paradigm shift? Circulation 89 : 493-498, 1994

7. Ruiz-Ortega M, Lorenzo O, Ruperez M, Esteban V, Suzuki Y, Mezzano S, Plaza JJ, Egido J : Role of the renin-angiotensin system in vascular diseases : expanding the field. Hypertension 38 : 1382-1387, 2001

8. Cheng HF, Becker BN, Burns KD, Harris RC : Angiotensin II upregulates type-1 angiotensin II receptors in renal proximal tubule. J Clin Invest 95 : 2012-2019, 1995

9. Lafayette RA, Mayer G, Park SK, Meyer TW : Angiotensin II receptor blockade limits glomerular injury in rats with reduced renal mass. J Clin Invest 90 : 766-771, 1992

10. Morimoto S, Cassell MD, Sigmund CD : The brain renin-angiotensin system in transgenic mice carrying a highly regulated human renin transgene. Circ Res $90: 80-86,2002$

11. Phillips MI, Sumners $C$ : Angiotensin II in central nervous system physiology. Regul Pept 78 : 1-11, 1998

12. Yang RH, Jin H, Wyss JM, Oparil S : Depressor effect of blocking angiotensin subtype 1 receptors in anterior hypothalamus. Hypertension 19 : 475-481, 1992

13. Iwai $\mathrm{N}$, Inagami $\mathrm{T}$ : Identification of two subtypes in the rat type I angiotensin II receptor. FEBS Lett 298 : 257-260, 1992

14. Morishita R, Gibbons GH, Ellison KE, Nakajima M, Zhang L, Kaneda Y, Ogihara T, Dzau VJ : Single intraluminal delivery of antisense cdc2 kinase and proliferating-cell nuclear antigen 
oligonucleotides results in chronic inhibition of neointimal hyperplasia. Proc Natl Acad Sci USA 90 : 8474-8478, 1993

15. Stoll M, Steckelings UM, Paul M, Bottari SP, Metzger R, Unger T: The angiotensin AT2receptor mediates inhibition of cell proliferation in coronary endothelial cells. J Clin Invest 95 : 651-657, 1995

16. Ferrario CM, Brosnihan KB, Diz DI, Jaiswal N, Khosla MC, Milsted A, Tallant EA: Angiotensin-(1-7) : a new hormone of the angiotensin system. Hypertension 18 : III126III133, 1991

17. Arakawa $\mathrm{K}$, Urata $\mathrm{H}$ : Hypothesis regarding the pathophysiological role of alternative pathways of angiotensin II formation in atherosclerosis. Hypertension 36 : 638-641, 2000

18. Schiffrin EL, Park JB, Intengan HD, Touyz $\mathrm{RM}$ : Correction of arterial structure and endothelial dysfunction in human essential hypertension by the angiotensin receptor antagonist losartan. Circulation 101 : 1653-1659, 2000

19. Varin R, Mulder P, Tamion F, Richard V, Henry JP, Lallemand F, Lerebours G, Thuillez $\mathrm{C}$ : Improvement of endothelial function by chronic angiotensin-converting enzyme inhibition in heart failure : role of nitric oxide, prostanoids, oxidant stress, and bradykinin. Circulation $102: 351-356,2000$

20. Pfeffer MA, McMurray JJ, Velazquez EJ, Rouleau JL, Kober L, Maggioni AP, Solomon SD, Swedberg K, Van de Werf F, White H, Leimberger JD, Henis M, Edwards S, Zelenkofske S, Sellers MA, Califf RM : Valsartan, captopril, or both in myocardial infarction complicated by heart failure, left ventricular dysfunction, or both. N Engl J Med 349 : 18931906, 2003

21. Pitt B, Segal R, Martinez FA, Meurers G, Cowley AJ, Thomas I, Deedwania PC, Ney DE, Snavely DB, Chang PI : Randomised trial of losartan versus captopril in patients over 65 with heart failure (Evaluation of Losartan in the Elderly Study, ELITE). Lancet 349 : 747-752, 1997

22. Chapman N, Huxley R, Anderson C, Bousser MG, Chalmers J, Colman S, Davis S, Donnan G, MacMahon S, Neal B, Warlow C, Woodward $\mathrm{M}$ : Effects of a perindopril-based blood pressure- lowering regimen on the risk of recurrent stroke according to stroke subtype and medical history : the PROGRESS Trial. Stroke 35 :
116-121, 2004

23. Schrader J, Luders S, Kulschewski A, Berger J, Zidek W, Treib J, Einhaupl K, Diener HC, Dominiak P: The ACCESS Study : evaluation of Acute Candesartan Cilexetil Therapy in Stroke Survivors. Stroke 34 : 1699-1703, 2003

24. Barnett AH, Bain SC, Bouter P, Karlberg B, Madsbad S, Jervell J, Mustonen J : Angiotensinreceptor blockade versus converting-enzyme inhibition in type 2 diabetes and nephropathy. N Engl J Med 351 : 1952-1961, 2004

25. Strippoli GF, Craig M, Deeks JJ, Schena FP, Craig JC : Effects of angiotensin converting enzyme inhibitors and angiotensin II receptor antagonists on mortality and renal outcomes in diabetic nephropathy : systematic review. BMJ 329 : 828, 2004

26. Yusuf S, Sleight P, Pogue J, Bosch J, Davies $R$, Dagenais G : Effects of an angiotensin-converting-enzyme inhibitor, ramipril, on cardiovascular events in high-risk patients. The Heart Outcomes Prevention Evaluation Study Investigators. N Engl J Med 342 : 145-153, 2000

27. Schrader J, Luders S, Kulschewski A, Hammersen F, Plate K, Berger J, Zidek W, Dominiak P, Diener HC : Morbidity and Mortality After Stroke, Eprosartan Compared with Nitrendipine for Secondary Prevention : principal results of a prospective randomized controlled study (MOSES). Stroke 36 : 1218-1226, 2005

28. Lusis AJ : Atherosclerosis. Nature 407 : 233241, 2000

29. Brasier AR, Recinos A, 3rd, Eledrisi MS : Vascular inflammation and the renin-angiotensin system. Arterioscler Thromb Vasc Biol 22 : 1257-1266, 2002

30. Ross R: Atherosclerosis--an inflammatory disease. N Engl J Med 340 : 115-126, 1999

31. Phillips MI, Kagiyama S : Angiotensin II as a pro-inflammatory mediator. Curr Opin Investig Drugs 3 : 569-577, 2002

32. Dean NM, Boynton AL : Angiotensin II causes phosphatidylinositol turnover and increases 1,2-diacylglycerol mass but is not mitogenic in rat liver T51B cells. Biochem J 269 : 347-352, 1990

33. Rodgers KE, DeCherney AH, St Amand KM, Dougherty WR, Felix JC, Girgis WW, diZerega GS : Histologic alterations in dermal repair after thermal injury effects of topical angiotensin II. J Burn Care Rehabil 18 : 381-388, 1997 
34. Stouffer GA, Owens GK: Angiotensin II-induced mitogenesis of spontaneously hypertensive rat-derived cultured smooth muscle cells is dependent on autocrine production of transforming growth factor-beta. Circ Res $70: 820$ 828, 1992

35. Fukuda D, Sata M, Ishizaka N, Nagai R : Critical role of bone marrow angiotensin II type 1 receptor in the pathogenesis of atherosclerosis in apolipoprotein $\mathrm{E}$ deficient mice. Arterioscler Thromb Vasc Biol 28 : 90-96, 2008

36. Fukuda D, Sata $\mathrm{M}$ : Role of bone marrow reninangiotensin system in the pathogenesis of atherosclerosis. Pharmacol Ther 118 : 268-276, 2008

37. Pueyo ME, Gonzalez W, Nicoletti A, Savoie F, Arnal JF, Michel JB : Angiotensin II stimulates endothelial vascular cell adhesion molecule-1 via nuclear factor-kappaB activation induced by intracellular oxidative stress. Arterioscler Thromb Vasc Biol 20 : 645-651, 2000

38. Pastore L, Tessitore A, Martinotti S, Toniato E, Alesse E, Bravi MC, Ferri C, Desideri G, Gulino A, Santucci A : Angiotensin II stimulates intercellular adhesion molecule-1 (ICAM-1) expression by human vascular endothelial cells and increases soluble ICAM-1 release in vivo. Circulation 100 : 1646-1652, 1999

39. Hernandez-Presa M, Bustos C, Ortego M, Tunon J, Renedo G, Ruiz-Ortega M, Egido J : Angiotensin-converting enzyme inhibition prevents arterial nuclear factor-kappa $B$ activation, monocyte chemoattractant protein-1 expression, and macrophage infiltration in a rabbit model of early accelerated atherosclerosis. Circulation 95 : 1532-1541, 1997

40. Petnehazy T, Stokes KY, Wood KC, Russell J, Granger DN : Role of blood cell-associated AT1 receptors in the microvascular responses to hypercholesterolemia. Arterioscler Thromb Vasc Biol 26 : 313-318, 2006

41. Kim JA, Berliner JA, Nadler JL : Angiotensin II increases monocyte binding to endothelial cells. Biochem Biophys Res Commun 226 : 862-868, 1996

42. Nouet $\mathrm{S}$, Nahmias $\mathrm{C}$ : Signal transduction from the angiotensin II AT2 receptor. Trends Endocrinol Metab $11: 1-6,2000$

43. Sayeski PP, Bernstein KE : Signal transduction mechanisms of the angiotensin II type AT(1)receptor : looking beyond the heterotrimeric $\mathrm{G}$ protein paradigm. J Renin Angiotensin Aldosterone Syst $2: 4-10,2001$
44. Falkenhahn M, Franke F, Bohle RM, Zhu YC, Stauss HM, Bachmann S, Danilov S, Unger T : Cellular distribution of angiotensin-converting enzyme after myocardial infarction. Hypertension 25 : 219-226, 1995

45. Fernandez-Alfonso MS, Martorana PA, Licka I, van Even P, Trobisch D, Scholkens BA, Paul $\mathrm{M}$ : Early induction of angiotensin I-converting enzyme in rat carotid artery after balloon injury. Hypertension 30 : 272-277, 1997

46. Wilson SK, Lynch DR, Snyder SH : Angiotensinconverting enzyme labeled with $[3 \mathrm{H}]$ captopril. Tissue localizations and changes in different models of hypertension in the rat. J Clin Invest $80: 841-851,1987$

47. Campbell DJ, Habener JF : Angiotensinogen gene is expressed and differentially regulated in multiple tissues of the rat. J Clin Invest 78 : 31-39, 1986

48. Hellmann W, Suzuki F, Ohkubo H, Nakanishi S, Ludwig G, Ganten D : Angiotensinogen gene expression in extrahepatic rat tissues : application of a solution hybridization assay. Naunyn Schmiedebergs Arch Pharmacol 338 : 327-331, 1988

49. Daugherty A, Rateri DL, Lu H, Inagami T, Cassis LA : Hypercholesterolemia stimulates angiotensin peptide synthesis and contributes to atherosclerosis through the AT1A receptor. Circulation $110: 3849-3857,2004$

50. Iwai N, Izumi M, Inagami $T$, Kinoshita $M$ : Induction of renin in medial smooth muscle cells by balloon injury. Hypertension 29 : 1044-1050, 1997

51. Tummala PE, Chen XL, Sundell CL, Laursen JB, Hammes CP, Alexander RW, Harrison DG, Medford RM : Angiotensin II induces vascular cell adhesion molecule- 1 expression in rat vasculature : A potential link between the reninangiotensin system and atherosclerosis. Circulation 100 : 1223-1229, 1999

52. Gu L, Okada Y, Clinton SK, Gerard C, Sukhova GK, Libby P, Rollins BJ : Absence of monocyte chemoattractant protein-1 reduces atherosclerosis in low density lipoprotein receptor-deficient mice. Mol Cell $2: 275-281,1998$

53. Han Y, Runge MS, Brasier AR : Angiotensin II induces interleukin- 6 transcription in vascular smooth muscle cells through pleiotropic activation of nuclear factor-kappa B transcription factors. Circ Res 84 : 695-703, 1999

54. Brasier AR, Jamaluddin M, Han Y, Patterson C, 
Runge MS : Angiotensin II induces gene transcription through cell-type-dependent effects on the nuclear factor-kappaB (NF-kappaB) transcription factor. Mol Cell Biochem 212 : 155169,2000

55. Harrison DG : Cellular and molecular mechanisms of endothelial cell dysfunction. J Clin Invest $100: 2153-2157,1997$

56. Daugherty A, Manning MW, Cassis LA : Angiotensin II promotes atherosclerotic lesions and aneurysms in apolipoprotein E-deficient mice. J Clin Invest 105 : 1605-1612, 2000

57. Keidar S, Heinrich R, Kaplan M, Hayek T, Aviram M : Angiotensin II administration to atherosclerotic mice increases macrophage uptake of oxidized ldl : a possible role for interleukin-6. Arterioscler Thromb Vasc Biol 21 : 1464-1469, 2001

58. Griendling KK, Ushio-Fukai M, Lassegue B, Alexander RW : Angiotensin II signaling in vascular smooth muscle. New concepts. Hypertension $29: 366-373,1997$

59. Chen J, Li D, Schaefer RF, Mehta JL: Inhibitory effect of candesartan and rosuvastatin on CD40 and MMPs expression in apo-E knockout mice : novel insights into the role of RAS and dyslipidemia in atherogenesis. J Cardiovasc Pharmacol 44 : 446-452, 2004

60. Galis ZS, Khatri JJ : Matrix metalloproteinases in vascular remodeling and atherogenesis : the good, the bad, and the ugly. Circ Res 90 : 251262,2002

61. Luchtefeld M, Grote K, Grothusen C, Bley S, Bandlow N, Selle T, Struber M, Haverich A, Bavendiek U, Drexler H, Schieffer B:Angiotensin II induces MMP-2 in a p47phoxdependent manner. Biochem Biophys Res Commun 328 : 183-188, 2005

62. Vaughan DE, Lazos SA, Tong K : Angiotensin II regulates the expression of plasminogen activator inhibitor-1 in cultured endothelial cells. A potential link between the renin-angiotensin system and thrombosis. J Clin Invest 95 : 9951001, 1995

63. Williams B, Baker AQ, Gallacher B, Lodwick $\mathrm{D}$ : Angiotensin II increases vascular permeability factor gene expression by human vascular smooth muscle cells. Hypertension 25 : 913917, 1995

64. Moreno PR, Purushothaman KR, Sirol M, Levy AP, Fuster V : Neovascularization in human atherosclerosis. Circulation $113: 2245-2252$,
2006

65. Cheng $\mathrm{C}$, Tempel $\mathrm{D}$, van Haperen $\mathrm{R}$, van der Baan A, Grosveld F, Daemen MJ, Krams R, de Crom R: Atherosclerotic lesion size and vulnerability are determined by patterns of fluid shear stress. Circulation $113: 2744-2753,2006$

66. Li Z, Iwai M, Wu L, Liu HW, Chen R, Jinno T, Suzuki J, Tsuda M, Gao XY, Okumura M, Cui TX, Horiuchi M : Fluvastatin enhances the inhibitory effects of a selective AT1 receptor blocker, valsartan, on atherosclerosis. Hypertension $44: 758-763,2004$

67. Wassmann S, Czech T, van Eickels M, Fleming I, Bohm M, Nickenig G : Inhibition of diet-induced atherosclerosis and endothelial dysfunction in apolipoprotein $\mathrm{E} /$ angiotensin II type $1 \mathrm{~A}$ receptor double-knockout mice. Circulation $110: 3062-3067,2004$

68. Fukuda D, Enomoto S, Nagai R, Sata M : Inhibition of renin-angiotensin system attenuates periadventitial inflammation and reduces atherosclerotic lesion formation. Biomed Pharmacother 63 : 754-761, 2009

69. Strawn WB, Chappell MC, Dean RH, Kivlighn $\mathrm{S}$, Ferrario $\mathrm{CM}$ : Inhibition of early atherogenesis by losartan in monkeys with diet-induced hypercholesterolemia. Circulation 101 : 15861593, 2000

70. Warnholtz A, Nickenig G, Schulz E, Macharzina R, Brasen JH, Skatchkov M, Heitzer T, Stasch JP, Griendling KK, Harrison DG, Bohm M, Meinertz T, Munzel T: Increased NADH-oxidase-mediated superoxide production in the early stages of atherosclerosis : evidence for involvement of the renin-angiotensin system. Circulation 99 : 2027-2033, 1999

71. Grossman E, Peleg E, Carroll J, Shamiss A, Rosenthal $\mathrm{T}$ : Hemodynamic and humoral effects of the angiotensin II antagonist losartan in essential hypertension. Am J Hypertens 7 : 1041-1044, 1994

72. Batenburg WW, Tom B, Schuijt MP, Danser $\mathrm{AH}$ : Angiotensin II type 2 receptor-mediated vasodilation. Focus on bradykinin, NO and endothelium-derived hyperpolarizing factor(s). Vascul Pharmacol 42 : 109-118, 2005

73. Iwai M, Chen R, Li Z, Shiuchi T, Suzuki J, Ide A, Tsuda M, Okumura M, Min LJ, Mogi M, Horiuchi $\mathrm{M}$ : Deletion of angiotensin II type 2 receptor exaggerated atherosclerosis in apolipoprotein E-null mice. Circulation 112 : 16361643, 2005 
74. Sales VL, Sukhova GK, Lopez-Ilasaca MA, Libby P, Dzau VJ, Pratt RE : Angiotensin type 2 receptor is expressed in murine atherosclerotic lesions and modulates lesion evolution. Circulation $112: 3328-3336,2005$

75. Wu L, Iwai M, Nakagami H, Li Z, Chen R, Suzuki J, Akishita M, de Gasparo M, Horiuchi $\mathrm{M}$ : Roles of angiotensin II type 2 receptor stimulation associated with selective angiotensin II type 1 receptor blockade with valsartan in the improvement of inflammation-induced vascular injury. Circulation 104 : 2716-2721, 2001

76. Wu L, Iwai M, Nakagami H, Chen R, Suzuki J, Akishita M, de Gasparo M, Horiuchi M : Effect of angiotensin II type 1 receptor blockade on cardiac remodeling in angiotensin II type 2 receptor null mice. Arterioscler Thromb Vasc Biol 22 : 49-54, 2002

77. Nakagami H, Cui TX, Iwai M, Shiuchi T, Takeda-Matsubara Y, Wu L, Horiuchi M : Tumor necrosis factor-alpha inhibits growth factormediated cell proliferation through SHP-1 activation in endothelial cells. Arterioscler Thromb Vasc Biol 22 : 238-242, 2002

78. Griendling KK, Sorescu D, Ushio-Fukai M : $\mathrm{NAD}(\mathrm{P}) \mathrm{H}$ oxidase : role in cardiovascular biology and disease. Circ Res 86 : 494-501, 2000

79. Barry-Lane PA, Patterson C, van der Merwe M, Hu Z, Holland SM, Yeh ET, Runge MS : $\mathrm{p} 47 \mathrm{phox}$ is required for atherosclerotic lesion progression in ApoE(-/-) mice. J Clin Invest 108: 1513-1522, 2001

80. Viedt C, Soto U, Krieger-Brauer HI, Fei J, Elsing C, Kubler W, Kreuzer J : Differential activation of mitogen-activated protein kinases in smooth muscle cells by angiotensin II : involvement of $\mathrm{p} 22$ phox and reactive oxygen species. Arterioscler Thromb Vasc Biol 20 : 940-948, 2000

81. Ushio-Fukai M, Alexander RW, Akers M, Yin Q, Fujio Y, Walsh K, Griendling KK : Reactive oxygen species mediate the activation of Akt/ protein kinase B by angiotensin II in vascular smooth muscle cells. J Biol Chem 274 : 2269922704, 1999

82. Schieffer B, Luchtefeld M, Braun S, Hilfiker A, Hilfiker-Kleiner D, Drexler $\mathrm{H}$ : Role of $\mathrm{NAD}(\mathrm{P}) \mathrm{H}$ oxidase in angiotensin II-induced JAK/STAT signaling and cytokine induction. Circ Res 87 : 1195-1201, 2000

83. Yang D, Elner SG, Bian ZM, Till GO, Petty HR,
Elner VM : Pro-inflammatory cytokines increase reactive oxygen species through mitochondria and NADPH oxidase in cultured RPE cells. Exp Eye Res 85 : 462-472, 2007

84. Verma S, Strauss M : Angiotensin receptor blockers and myocardial infarction. Bmj 329 : 1248-1249, 2004

85. Hayek T, Attias J, Coleman R, Brodsky S, Smith J, Breslow JL, Keidar S : The angiotensinconverting enzyme inhibitor, fosinopril, and the angiotensin II receptor antagonist, losartan, inhibit LDL oxidation and attenuate atherosclerosis independent of lowering blood pressure in apolipoprotein E deficient mice. Cardiovasc Res 44 : 579-587, 1999

86. Schmeisser A, Soehnlein O, Illmer T, Lorenz HM, Eskafi S, Roerick O, Gabler C, Strasser R, Daniel WG, Garlichs CD : ACE inhibition lowers angiotensin II-induced chemokine expression by reduction of NF-kappaB activity and AT1 receptor expression. Biochem Biophys Res Commun 325 : 532-540, 2004

87. Cathcart MK : Regulation of superoxide anion production by NADPH oxidase in monocytes/ macrophages : contributions to atherosclerosis. Arterioscler Thromb Vasc Biol 24 : 23-28, 2004

88. Keidar S, Kaplan M, Pavlotzky E, Coleman R, Hayek T, Hamoud S, Aviram M : Aldosterone administration to mice stimulates macrophage $\mathrm{NADPH}$ oxidase and increases atherosclerosis development: a possible role for angiotensinconverting enzyme and the receptors for angiotensin II and aldosterone. Circulation 109 : 2213-2220, 2004

89. Hoshida S, Kato J, Nishino M, Egami Y, Takeda T, Kawabata M, Tanouchi J, Yamada Y, Kamada $\mathrm{T}$ : Increased angiotensin-converting enzyme activity in coronary artery specimens from patients with acute coronary syndrome. Circulation $103: 630-633,2001$

90. Diet F, Pratt RE, Berry GJ, Momose N, Gibbons GH, Dzau VJ : Increased accumulation of tissue ACE in human atherosclerotic coronary artery disease. Circulation $94: 2756-2767$, 1996

91. Schieffer B, Schieffer E, Hilfiker-Kleiner D, Hilfiker A, Kovanen PT, Kaartinen M, Nussberger J, Harringer W, Drexler H : Expression of angiotensin II and interleukin 6 in human coronary atherosclerotic plaques : potential implications for inflammation and plaque instability. Circulation 101: 1372-1378, 2000 
92. Ezoe S, Matsumura I, Satoh Y, Tanaka H, Kanakura Y : Cell cycle regulation in hematopoietic stem/progenitor cells. Cell Cycle 3 : 314-318, 2004

93. Heissig B, Ohki Y, Sato Y, Rafii S, Werb Z, Hattori $\mathrm{K}$ : A role for niches in hematopoietic cell development. Hematology $10: 247-253$, 2005

94. Sensebe L, Deschaseaux M, Li J, Herve P, Charbord P: The broad spectrum of cytokine gene expression by myoid cells from the human marrow microenvironment. Stem Cells $15: 133-143,1997$

95. Nomura S, Sasaki T, Kitano Y, Osawa G : Effects of ACE inhibitor on renal anemia in predialysis patients. Nephron 73 : 336-337, 1996

96. Nomura S, Sugihara T, Tomiyama T, Kitano Y, Yawata Y, Osawa G : Polycythaemia vera : response to treatment with angiotensin-converting enzyme inhibitor. Eur J Haematol 57 : 117119, 1996

97. Vasku A, Soucek M, Znojil V, Rihacek I, Cidl K, Strelcova L, Vacha J : Does angiotensin Iconverting enzyme inhibitor therapy have an antiproliferative effect on blood-forming bone marrow? Exp Hematol 26 : 277-279, 1998

98. Conlon PJ, Smith SR, Butterly DW, Brennan DC : Losartan in post-transplant erythrocytosis. Nephrol Dial Transplant 11 : 2524-2525, 1996

99. Rell K, Koziak K, Jarzyo I, Lao M, Gaciong Z : Correction of posttransplant erythrocytosis with enalapril. Transplantation 57 : 1059-1063, 1994

100. Haznedaroglu IC, Tuncer S, Gursoy M : A local renin-angiotensin system in the bone marrow. Med Hypotheses 46 : 507-510, 1996

101. Rodgers KE, Xiong S, Steer R, diZerega GS : Effect of angiotensin II on hematopoietic progenitor cell proliferation. Stem Cells 18 : 287294, 2000

102. Rodgers K, Xiong S, DiZerega GS : Effect of angiotensin II and angiotensin(1-7) on hematopoietic recovery after intravenous chemotherapy. Cancer Chemother Pharmacol 51 : 97-106, 2003

103. Rodgers KE, Xiong S, diZerega GS : Accelerated recovery from irradiation injury by angiotensin peptides. Cancer Chemother Pharmacol 49 : 403-411, 2002

104. Chisi JE, Wdzieczak-Bakala J, Riches AC : Inhibitory action of the peptide AcSDKP on the proliferative state of hematopoietic stem cells in the presence of captopril but not lisinopril.
Stem Cells 15 : 455-460, 1997

105. Comte L, Lorgeot V, Volkov L, Allegraud A, Aldigier JC, Praloran V: Effects of the angiotensin-converting enzyme inhibitor enalapril on blood haematopoietic progenitors and acetylN-Ser-Asp-Lys-Pro concentrations. Eur J Clin Invest 27 : 788-790, 1997

106. Mrug M, Stopka T, Julian BA, Prchal JF, Prchal $\mathrm{JT}$ : Angiotensin II stimulates proliferation of normal early erythroid progenitors. J Clin Invest $100: 2310-2314,1997$

107. Abali H, Haznedaroglu IC, Goker H, Celik I, Ozatli D, Koray Z, Caglar M : Circulating and local bone marrow renin-angiotensin system in leukemic hematopoiesis : preliminary evidences. Hematology 7 : 75-82, 2002

108. Wulf GG, Jahns-Streubel G, Nobiling R, Strutz F, Hemmerlein B, Hiddemann W, Wormann $\mathrm{B}:$ Renin in acute myeloid leukaemia blasts. Br J Haematol 100 : 335-337, 1998

109. Haznedaroglu IC, Ozturk MA: Towards the understanding of the local hematopoietic bone marrow renin-angiotensin system. Int J Biochem Cell Biol 35 : 867-880, 2003

110. Sata M, Tanaka K, Nagai R: Origin of smooth muscle progenitor cells : different conclusions from different models. Circulation 107 : e106e107, 2003

111. Sata M, Tanaka K, Nagai R: Circulating osteoblast-lineage cells. N Engl J Med 353 : 737738 ; author reply 737-738, 2005

112. Sata M : Molecular strategies to treat vascular diseases. Circ J 67 : 983-991., 2003

113. Sata M : Role of circulating vascular progenitors in angiogenesis, vascular healing, and pulmonary hypertension : lessons from animal models. Arterioscler Thromb Vasc Biol 26 : 1008-1014, 2006

114. Sata M : Circulating vascular progenitor cells contribute to vascular repair, remodeling, and lesion formation. Trends Cardiovasc Med 13 : 249-253, 2003

115. Fukuda D, Shimada K, Tanaka A, Kawarabayashi T, Yoshiyama M, Yoshikawa J : Circulating monocytes and in-stent neointima after coronary stent implantation. J Am Coll Cardiol $43:$ 18-23, 2004

116. Fukuda D, Sata M, Tanaka K, Nagai R : Potent inhibitory effect of sirolimus on circulating vascular progenitor cells. Circulation 111 : 926931, 2005

117. Fukuda D, Sata M : The renin-Angiotensin 
system : a potential modulator of endothelial progenitor cells. Hypertens Res 30 : 1017-1018, 2007

118. Caplice NM, Bunch TJ, Stalboerger PG, Wang S, Simper D, Miller DV, Russell SJ, Litzow MR, Edwards WD : Smooth muscle cells in human coronary atherosclerosis can originate from cells administered at marrow transplantation. Proc Natl Acad Sci USA 100 : 4754-4759, 2003

119. Quaini F, Urbanek K, Beltrami AP, Finato N, Beltrami CA, Nadal-Ginard B, Kajstura J, Leri A, Anversa P : Chimerism of the transplanted heart. N Engl J Med 346 : 5-15., 2002

120. Zhang SH, Reddick RL, Piedrahita JA, Maeda $\mathrm{N}$ : Spontaneous hypercholesterolemia and arterial lesions in mice lacking apolipoprotein E. Science 258 : 468-471, 1992

121. Sugaya T, Nishimatsu S, Tanimoto K, Takimoto E, Yamagishi T, Imamura K, Goto S, Imaizumi K, Hisada Y, Otsuka A, et al. : Angiotensin II type 1a receptor-deficient mice with hypotension and hyperreninemia. J Biol Chem 270 : 18719-18722, 1995

122. Tsuchida S, Matsusaka T, Chen X, Okubo S, Niimura $F$, Nishimura $H$, Fogo A, Utsunomiya $\mathrm{H}$, Inagami $\mathrm{T}$, Ichikawa I : Murine double nullizygotes of the angiotensin type $1 \mathrm{~A}$ and $1 \mathrm{~B}$ receptor genes duplicate severe abnormal phenotypes of angiotensinogen nullizygotes. J Clin Invest 101 : 755-760, 1998

123. Cassis LA, Rateri DL, Lu H, Daugherty A: Bone marrow transplantation reveals that recipient AT1a receptors are required to initiate angiotensin II-induced atherosclerosis and aneurysms. Arterioscler Thromb Vasc Biol 27 : 380-386, 2007

124. Schwartz SM : Perspectives series : cell adhesion in vascular biology. Smooth muscle migration in atherosclerosis and restenosis. J Clin Invest 99 : 2814-2816, 1997

125. Bauters C, Isner JM : The biology of restenosis. Prog Cardiovasc Dis 40 : 107-116, 1997

126. Libby P, Schwartz D, Brogi E, Tanaka H, Clinton SK : A cascade model for restenosis. A special case of atherosclerosis progression. Circulation 86 : III47-III52, 1992

127. Carmeliet P, Moons L, Stassen JM, De Mol M, Bouche A, van den Oord JJ, Kockx M, Collen $\mathrm{D}$ : Vascular wound healing and neointima formation induced by perivascular electric injury in mice. Am J Pathol 150 : 761-776, 1997

128. Asahara T, Masuda H, Takahashi T, Kalka C,
Pastore C, Silver M, Kearne M, Magner M, Isner JM : Bone marrow origin of endothelial progenitor cells responsible for postnatal vasculogenesis in physiological and pathological neovascularization. Circ Res 85 : 221-228, 1999

129. Asahara T, Murohara T, Sullivan A, Silver M, van der Zee R, Li T, Witzenbichler B, Schatteman G, Isner JM : Isolation of putative progenitor endothelial cells for angiogenesis. Science 275 : 964-967, 1997

130. Gill M, Dias S, Hattori K, Rivera ML, Hicklin D, Witte L, Girardi L, Yurt R, Himel H, Rafii S : Vascular trauma induces rapid but transient mobilization of VEGFR2(+)AC133(+) endothelial precursor cells. Circ Res $88: 167-174,2001$

131. Orlic D, Kajstura J, Chimenti S, Bodine DM, Leri A, Anversa P : Transplanted adult bone marrow cells repair myocardial infarcts in mice. Ann NY Acad Sci $938: 221-229$; discussion 229-230, 2001

132. Crosby JR, Kaminski WE, Schatteman G, Martin PJ, Raines EW, Seifert RA, BowenPope DF : Endothelial cells of hematopoietic origin make a significant contribution to adult blood vessel formation. Circ Res 87 : 728-730, 2000

133. Ikenaga S, Hamano K, Nishida M, Kobayashi T, Li TS, Kobayashi S, Matsuzaki M, Zempo $\mathrm{N}$, Esato $\mathrm{K}$ : Autologous bone marrow implantation induced angiogenesis and improved deteriorated exercise capacity in a rat ischemic hindlimb model. J Surg Res 96 : 277-283, 2001

134. Kawamoto A, Gwon HC, Iwaguro H, Yamaguchi JI, Uchida S, Masuda H, Silver M, Ma H, Kearney M, Isner JM, Asahara T: Therapeutic potential of ex vivo expanded endothelial progenitor cells for myocardial ischemia. Circulation 103 : 634-637, 2001

135. Shintani S, Murohara T, Ikeda H, Ueno T, Honma T, Katoh A, Sasaki K, Shimada T, Oike Y, Imaizumi T: Mobilization of endothelial progenitor cells in patients with acute myocardial infarction. Circulation 103 : 2776-2779, 2001

136. Imanishi T, Hano T, Nishio I : Angiotensin II potentiates vascular endothelial growth factorinduced proliferation and network formation of endothelial progenitor cells. Hypertens Res 27 : 101-108, 2004

137. Ivanova NB, Dimos JT, Schaniel C, Hackney JA, Moore KA, Lemischka IR : A stem cell molecular signature. Science 298 : 601-604, 2002

138. Noble M, Smith J, Power J, Mayer-Proschel M : 
Redox state as a central modulator of precursor cell function. Ann NY Acad Sci 991 : 251271,2003

139. Ito K, Hirao A, Arai F, Takubo K, Matsuoka S, Miyamoto K, Ohmura M, Naka K, Hosokawa $\mathrm{K}$, Ikeda Y, Suda T : Reactive oxygen species act through p38 MAPK to limit the lifespan of hematopoietic stem cells. Nat Med 12 : 446451, 2006

140. Sasaki K, Murohara T, Ikeda H, Sugaya T, Shimada T, Shintani S, Imaizumi T: Evidence for the importance of angiotensin II type 1 receptor in ischemia-induced angiogenesis. J Clin Invest 109 : 603-611, 2002

141. Bahlmann FH, de Groot K, Mueller O, Hertel B,
Haller H, Fliser D : Stimulation of endothelial progenitor cells : a new putative therapeutic effect of angiotensin II receptor antagonists. Hypertension $45: 526-529,2005$

142. Imanishi T, Hano T, Nishio I : Angiotensin II accelerates endothelial progenitor cell senescence through induction of oxidative stress. J Hypertens 23 : 97-104, 2005

143. Yao EH, Yu Y, Fukuda N : Oxidative stress on progenitor and stem cells in cardiovascular diseases. Curr Pharm Biotechnol 7 : 101-108, 2006

144. Sata M, Nagai R : Inflammation, angiogenesis, and endothelial progenitor cells : how do endothelial progenitor cells find their place? J Mol Cell Cardiol 36 : 459-463, 2004 